\title{
The effect of environmental pH on the physiology and surface structures of Salmonella serotype Enteritidis phage type 4
}

\author{
ANN S. McDERMID, AILSA S. McKEE, A. B. DOWSETT and P. D. MARSH \\ Centre for Applied Microbiology and Research, Porton Down, Wiltshire SP4 OJG
}

\begin{abstract}
The incidence of food-poisoning caused by Salmonella serotype Enteritidis PT4 has increased. Implicated food products display pH levels between 4 and 9 . Accordingly, the effect of growth at extremes of $\mathrm{pH}$ on the presence of surface structures and the carriage of a 38-MDa plasmid was determined by growing a clinical isolate of Enteritidis PT4 in a chemostat. Steady-state growth was possible over the $\mathrm{pH}$ range $4.35-9.45$, corresponding to the $\mathrm{pH}$ extremes associated with key reservoirs implicated in outbreaks. Without pH control, cultures stabilised at $\mathrm{pH} 7.10$. Growth at extremes of pH had significant effects on the distribution of cell surface structures; at pH 9.45, only $3 \%$ of cells were fimbriate compared with $52 \%$ at $\mathrm{pH} 7.10$ and $20 \%$ at $\mathrm{pH} 4.35$. The proportion of motile cells and the presence of flagella was also reduced at extremes of pH. A 38-MDa plasmid was present in cells grown in the chemostat at $\mathbf{p H} \mathbf{7 . 1 0}$, but not in cells grown at $\mathrm{pH} 4.35$ or $\mathrm{pH}$ 9.45. Thus, environmental pH may have a significant impact on the virulence potential of Enteritidis PT4.
\end{abstract}

\section{Introduction}

Salmonellae are a major cause of foodborne disease in most developed countries. In recent years a significant increase in the number of reported cases of salmonellosis in man has been observed [1]. This has been associated mainly with an increase in infections caused by Salmonella enterica serotype Enteritidis ( $S$. enteritidis), especially of phage type (PT) 4 , in the UK, Europe and some other areas of the world [2].

Epidemiological investigations of foodborne salmonellosis have identified an important role for egg and poultry products as vehicles of sporadic outbreaks of disease [3]. Enteritidis PT4 causes invasive disease in poultry that leads to chronic infection of various organs. If the reproductive tissues become infected, transmission to eggs may occur [4,5]. Consequently, Enteritidis PT4 may be found in the contents of eggs and within poultry muscle, as well as contaminating the surface of these products.

Implicated food products display a wide range of environmental conditions in which Enteritidis PT4 must be able to survive and grow. For example, infected chicken meat has a $\mathrm{pH}$ around neutrality,

Received 20 Feb. 1996; revised version accepted 15 May 1996.

Corresponding author: Dr A. S. McDermid. whilst the $\mathrm{pH}$ of egg albumin is $>9$ [6]; furthermore, during the production of mayonnaise, the addition of acetic acid or citric acid to raw eggs reduces the $\mathrm{pH}$ of the product to $3.2-4.5$ [7]. Since environmental conditions dictate the phenotypic properties of bacteria, the source from which Enteritidis is derived may influence the virulence potential of cells, and modify their ability to survive subsequent stresses. Continuous-culture techniques were used to provide reproducible, steady-state bacterial growth under defined, pre-determined environmental conditions. Steady states can be maintained for long periods making it possible to study the effect of growth at selected $\mathrm{pH}$ values on the physiology of Enteritidis PT4, with other environmental conditions and growth rate remaining constant.

The aim of this study, therefore, was to determine the range of $\mathrm{pH}$ over which Enteritidis PT4 is able to grow and to determine the effect of growth at extremes of $\mathrm{pH}$ on selected properties of cells such as the presence of surface structures and the carriage of a plasmid, that might be related to pathogenicity.

\section{Materials and methods}

\section{Bacterial strain and growth conditions}

The strain of Enteritidis PT4 used (reference no. 226 405) was isolated at the Public Health Laboratory, Salisbury, from the faeces of a patient with food 
poisoning. To determine the $\mathrm{pH}$ range for growth and the effect of environmental $\mathrm{pH}$ on bacterial cell properties, it was grown in a chemostat ( $\mathrm{LH}$ Engineering, Inceltech, Reading, Berkshire) with a 500-ml working volume, in Vogel Bonner minimal medium [8] supplemented with vitamins [9] and glycoprotein (hog gastric mucin, Sigma) $0.25 \% \mathrm{w} / \mathrm{v}$ in an atmosphere of $\mathrm{CO}_{2} 5 \%$ and $\mathrm{N}_{2} 95 \%$ at $37^{\circ} \mathrm{C}$. The medium flow-rate was set to give a dilution rate of $0.1 / \mathrm{h}$, equivalent to a mean generation time of $6.9 \mathrm{~h}$. The $\mathrm{pH}$ range for growth was determined by increasing or decreasing the $\mathrm{pH}$ value until steady-state cultures could no longer be established. The $\mathrm{pH}$ in the culture vessel was maintained at the required values by automatic addition of $2 \mathrm{M} \mathrm{NaOH}$ or $2 \mathrm{M} \mathrm{HCl}$.

\section{Growth parameters}

At each $\mathrm{pH}$ value studied, cultures were allowed to achieve steady-state conditions before use. Ten potvolume changes of medium were allowed to occur ( 5 days at this dilution rate) before a culture was considered to have reached steady state. Purity of culture was confirmed daily by spreading a sample on nutrient agar plates which were incubated at $37^{\circ} \mathrm{C}$ in air; any variant colonies were confirmed as Enteritidis on selective media: XLD (Oxoid), Hektoen Enteric (HE, Lab M) and DCA Hynes (Lab M). Cell yields were determined daily by estimation of viable counts on nutrient agar after overnight incubation at $37^{\circ} \mathrm{C}$. The maximum specific growth rate $\left(\mu_{\max }\right)$ was determined by the wash-out method of Tempest [10]. Several estimations of $\mu_{\max }$ were made at different dilution rates and the maximum observed value was selected as being the best estimate of $\mu_{\max }$ under the test environmental conditions.

\section{Motility estimations}

Motility was assessed by light microscopy in a Thoma counting chamber (Hawksley, London). Fresh samples from each steady-state culture were examined for motile cells; formaldehyde $1 \% \mathrm{w} / \mathrm{v}$ was added before a total count was made. Motility was expressed as a proportion of the total cell count. Values from the chemostat cultures were compared with those of cells grown in Vogel Bonner medium ( $\mathrm{pH} \mathrm{7)}$ at $37^{\circ} \mathrm{C}$ for $18 \mathrm{~h}$ in batch cultures.

\section{Surface structures}

Cell morphology and surface structures were viewed by transmission electron microscopy. Culture samples were fixed by the addition of formaldehyde $0.5 \% \mathrm{w} / \mathrm{v}$, applied to formvar-carbon filmed, 400-mesh EM specimen grids with a disposable plastic loop which avoided cell damage from shearing forces. Grids were negatively stained with phosphotungstic acid $1 \% \mathrm{w} / \mathrm{v}$.

\section{Growth environment transitions}

The proportion of motile cells and the distribution of surface structures were also calculated after switching of cultures from one $\mathrm{pH}$ value to another. Initially, the chemostat culture was allowed to reach steady state at $\mathrm{pH}$ 9.45; $\mathrm{pH}$ control was then discontinued and, after $24 \mathrm{~h}$, the $\mathrm{pH}$ stabilised at $\mathrm{pH} 7.10$ and a new steady state was established. Cells were taken directly from the chemostat, before, during and after the transition, and were assessed for motility and surface structures, as described above.

\section{Plasmid content}

A 38-MDa plasmid, carried by some strains of Enteritidis, has been associated with virulence in mice [11]. After growth for 10 days at each steady state, plasmid profiles of cultures taken directly from the chemostat were determined and the presence of the 38MDa plasmid was assessed. A modification of the method described by Portnoy [12] was used, with extra care taken in the preparation of the alkaline denaturing solution [13], and the plasmid was precipitated from the neutralised, cleared lysate with polyethylene glycol [14]. Plasmid DNA was analysed by agarose-gel electrophoresis on agarose $0.7 \% \mathrm{w} / \mathrm{v}$ gels containing ethidium bromide $0.05 \mu \mathrm{g} / \mathrm{ml}$ and performed in Trisacetate buffer [15]. Gels were examined by UV transillumination. Plasmids in Escherichia coli strain $39 \mathrm{R} 861$ were also included as plasmid-size reference molecules [16]. Enteritidis PT4 strain p132344 and an isogenic variant strain p132344/1, which is plasmid free, were also included as controls [11].

\section{Data analysis}

Data on cell yields between chemostat runs at the same $\mathrm{pH}$ value and between different $\mathrm{pH}$ values were analysed by two-way analysis of variance, with a Statgraphics package (STC Inc., Rockville, MD, USA). Pairwise comparisons between cell yields at the three $\mathrm{pH}$ values were made by the Scheffé test. Differences were assumed to be significant at $\mathrm{p}<0.05$.

The proportions of cells with surface structures at the three different $\mathrm{pH}$ values were compared by use of the large-samples proportions test (assuming a normal distribution) [17]; again, differences were assumed to be significant at $\mathrm{p}<0.05$.

\section{Results \\ Growth characteristics of Enteritidis PT4 strain 226405}

Growth occurred in the chemostat over the $\mathrm{pH}$ range 4.35-9.45 under the conditions described; steady-state growth was not possible outwith this $\mathrm{pH}$ range. Without $\mathrm{pH}$ control, the culture stabilised at $\mathrm{pH} 7.10$ which, with the two extremes of $\mathrm{pH}$, were selected for 
more detailed studies. The reproducibility of repeat chemostat runs was good with no significant difference being detected between repeat runs by two-way analysis of variance $\left(\mathrm{F}_{[10,82]}=1.59, \mathrm{p}=0.125\right)$. Cell yields at the different $\mathrm{pH}$ levels were compared by two-way analysis of variance and were highly significantly different $\left(\mathrm{F}_{[2,10]}=404.1, \mathrm{p}<0.0001\right)$. Following analysis of variance, pair-wise comparisons of each combination of $\mathrm{pH}$ values were made by the Scheffé test. Each pair-wise comparison of cell yields was significantly different, with most of the variation due to greatly reduced cell yields being obtained at the extremes of $\mathrm{pH}$ compared to $\mathrm{pH} 7.10$ (Table 1).

The observed maximum growth rate was reduced at $\mathrm{pH}$ 4.35; such a reduction was not observed at $\mathrm{pH}$ 9.45 , at which the doubling time was $35 \mathrm{~min}$, the same as that measured at $\mathrm{pH} 7.10$ (Table 1).

\section{Cell motility}

A reduction in the proportion of motile cells was observed during continuous culture; $90 \%$ of batchculture cells were motile, compared with only c. $10 \%$ in continuous culture at $\mathrm{pH} 7.10$. The proportion of motile cells was reduced still further $(\sim 1 \%)$ during growth at the extreme $\mathrm{pH}$ values, and this reduction in motility correlated with the number of cells expressing flagella, as determined by electron microscopy (Table 2).

\section{Surface structures}

Growth at the extremes of $\mathrm{pH}$ in the chemostat had marked effects on the distribution of cell surface structures (Table 3 ). The number of cells with fimbriae was considerably reduced at $\mathrm{pH} 9.45$. A typical cell from a culture at $\mathrm{pH} 9.45$ is shown (Fig. 1); at this $\mathrm{pH}$ value, $95 \%$ of the bacterial cells had no surface structures, whereas only $42 \%$ of cells were devoid of structures when grown at a constant $\mathrm{pH}$ of 7.10. A cell from a culture grown at $\mathrm{pH} 7.10$, and expressing fimbriae but not flagella, is illustrated in Fig. 2. A
Table 1. Characteristics of Enteritidis strain 226405 grown in continuous culture at different $\mathrm{pH}$ values

\begin{tabular}{lccc}
\hline $\begin{array}{l}\text { Growth } \\
\mathrm{pH}\end{array}$ & $\begin{array}{c}\text { Cell } \\
\text { numbers } \\
\left(\log _{10} \mathrm{cfu} / \mathrm{ml}\right)\end{array}$ & $\begin{array}{c}\text { Maximum } \\
\text { growth rate/h } \\
\left(\mu_{\max }\right)\end{array}$ & $\begin{array}{c}\text { Maximum } \\
\text { doubling time } \\
(\mathrm{min})\end{array}$ \\
\hline 4.35 & $\begin{array}{c}7.24(0.19)^{*} \\
{[27] \dagger}\end{array}$ & 0.99 & 42 \\
7.10 & $\begin{array}{c}8.63(0.15) \\
{[45] \dagger}\end{array}$ & 1.20 & 35 \\
9.45 & $\begin{array}{c}6.96(0.45) \\
{[22] \dagger}\end{array}$ & 1.20 & 35 \\
& & & \\
\hline
\end{tabular}

* Standard deviation values shown in parentheses.

†Number of determinations shown in square brackets.

Table 2. Motility and presence of flagella on cells of Enteritidis PT4 grown under different culture conditions

\begin{tabular}{lccc}
\hline \multirow{2}{*}{$\begin{array}{l}\text { Growth } \\
\text { condition }\end{array}$} & $\mathrm{pH}$ & morcentage of bacterial cells that were \\
\cline { 2 - 4 } & 7.10 & $>90$ & flagellate* $^{*}$ \\
\hline Batch & 4.35 & 1 & $81(9)^{*}[4] \dagger$ \\
Continuous & 10 & $2(1)$ & {$[3]$} \\
Continuous & 7.10 & $<1$ & $8(4)[2]$ \\
Continuous & 9.45 & $2(2)[2]$
\end{tabular}

* Standard deviation values shown in parentheses.

$\dagger$ Number of determinations shown in square brackets.

reduction in surface structures was also observed at $\mathrm{pH}$ 4.35 , but to a lesser extent; $69 \%$ of the cells in this population were 'bald'. The proportion of cells expressing fimbriae was shown to be significantly different at the three $\mathrm{pH}$ values when the data were analysed by the large-sample proportions test, with $\mathrm{p}<0.001$ for all comparisons; most of the difference occurred between the extremes of $\mathrm{pH}$ (4.35 and 9.45) and $\mathrm{pH} 7.10$; comparison of $\mathrm{pH} 7.10$ with $\mathrm{pH} 4.35$ and with $\mathrm{pH} 9.45$ gave $Z=9.17, \mathrm{p}<0.00001$ and $\mathrm{Z}=23.4, \mathrm{p}<0.00001$, respectively. The proportion of cells expressing fimbriae was also shown to be significantly different between $\mathrm{pH} 4.35$ and 9.45 but at a lower level: $Z=4.30, p<0.00002$. A greater variation in the estimation of surface structures was observed with the low-pH culture, perhaps because mucin is less soluble at low $\mathrm{pH}$ values and coats the

Table 3. Surface structures detected on cells of Enteritidis PT4 grown in chemostat cultures at different $\mathrm{pH}$ values

\begin{tabular}{lcccc}
\hline & \multicolumn{4}{c}{ Percentage bacterial cells with } \\
\cline { 2 - 5 } $\begin{array}{l}\text { Steady state } \\
\text { growth pH }\end{array}$ & $\begin{array}{c}\text { fimbriae } \\
\text { only }\end{array}$ & $\begin{array}{c}\text { flagella } \\
\text { only }\end{array}$ & $\begin{array}{c}\text { both fimbriae } \\
\text { and flagella }\end{array}$ & neither \\
\hline 4.35 & $20(15)^{*}$ & $11(12)^{*}$ & 0 & $69(41)^{*}$ \\
7.10 & {$[2]^{\dagger}$} & {$[2] \dagger$} & {$[2] \dagger$} & {$[2] \dagger$} \\
9.45 & $52(16)$ & $6(4)$ & $1(1)$ & $42(14)$ \\
$9.45 \rightarrow 7.10 \ddagger$ & {$[4]$} & {$[4]$} & {$[4]$} & {$[4]$} \\
& $3(2)$ & $2(2)$ & 0 & $95(1)$ \\
& {$[4]$} & {$[4]$} & {$[4]$} & {$[4]$} \\
& $90(5)$ & $2(1)$ & $0.3(0.2)$ & $8(4)$ \\
\hline
\end{tabular}

* Standard deviation values are shown in parentheses.

+Number of determinations are shown in square brackets.

$\ddagger$ Culture, grown initially at $\mathrm{pH} 9.45$, then switched to $\mathrm{pH} 7.10$ 


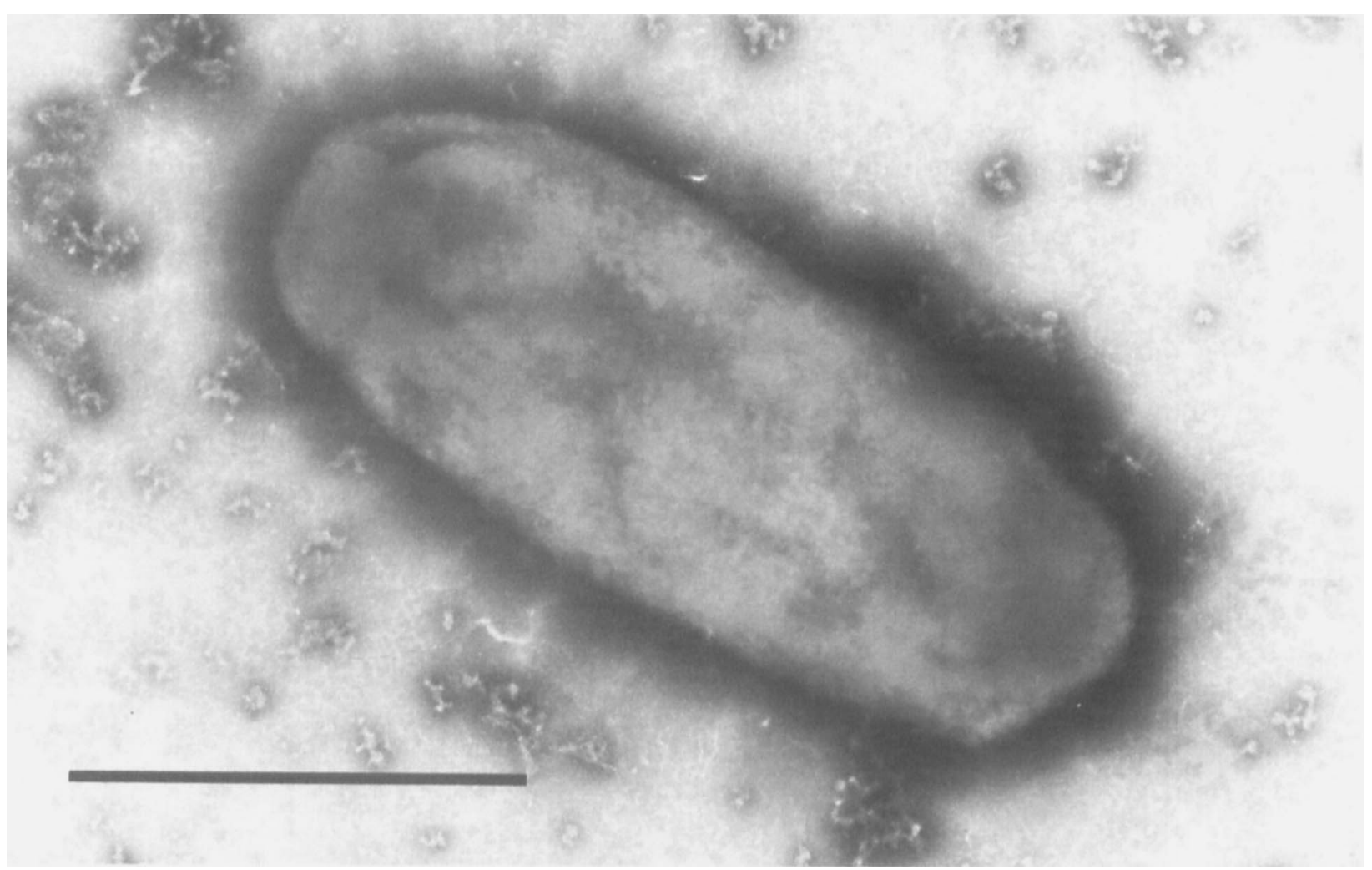

Fig. 1. Transmission electron micrograph of Salmonella serotype Enteritidis PT4 grown in chemostat culture at $\mathrm{pH} 9.45$ showing a bacterial cell with no surface structures. Bar $=1 \mu \mathrm{m}$.

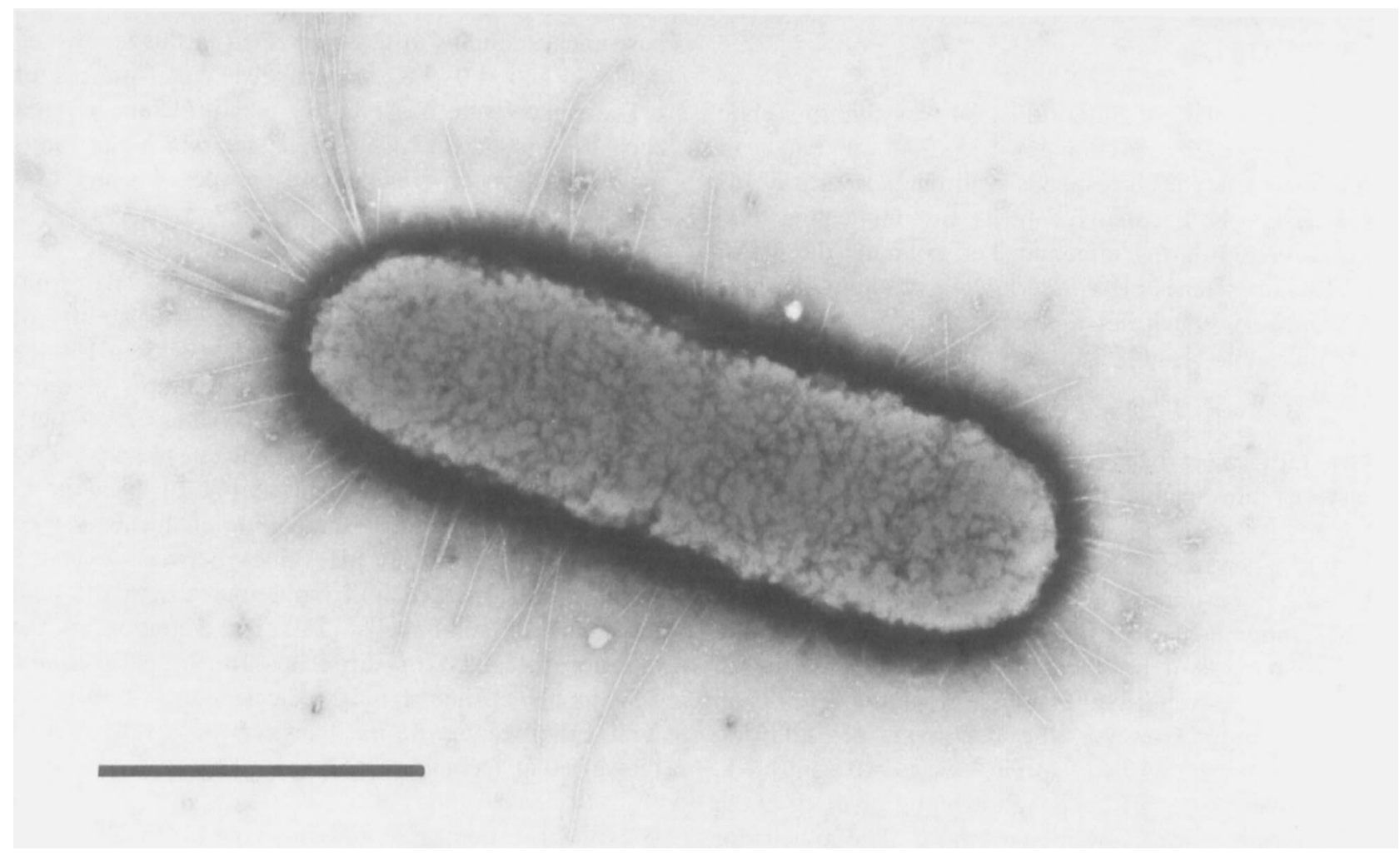

Fig. 2. Transmission electron micrograph of Salmonella serotype Enteritidis PT4 grown in chemostat culture at $\mathrm{pH} 7.1$ showing cells with many fimbriae. Bar $=1 \mu \mathrm{m}$. 
cell surface, so leading to less efficient staining and viewing. The proportion of flagellate cells was significantly higher at $\mathrm{pH} 7.10$ than at $\mathrm{pH} 9.45$ ( $\mathrm{Z}=4.96, \mathrm{p}<0.00001)$; however, there was no significant difference when compared to $\mathrm{pH}$ 4.35: $Z=0.55, p<0.60$. The proportion of cells with flagella was marginally higher at $\mathrm{pH} 4.35$ than at $\mathrm{pH}$ 9.45: $Z=2.18, \mathrm{p}<0.03$

\section{pH transition studies}

The surface structures of cells were monitored during a transition from $\mathrm{pH} 9.45$ to $\mathrm{pH} 7.10$. No cells expressing flagella were visible when viewed by electron microscopy at $\mathrm{pH} 9.45$ before the transition. The proportion of motile bacterial cells estimated by light microscopy was $<1 \%$. Within $1.5 \mathrm{~h}$ of discontinuing $\mathrm{pH}$ control, it had fallen to $\mathrm{pH} 8.79$ and the viable count was $6.0 \times 10^{6} \mathrm{cfu} / \mathrm{ml}$. After a further $1.5 \mathrm{~h}$, the $\mathrm{pH}$ was 8.4 , the viable count had increased to $1.5 \times 10^{7} \mathrm{cfu} / \mathrm{ml}$ and $18 \%$ of the cells were flagellate. When a steady state was achieved at $\mathrm{pH} \mathrm{7.10,} \mathrm{the} \mathrm{majority} \mathrm{of} \mathrm{cells} \mathrm{were}$ fimbriate (Table 3 ).

\section{Plasmid content}

A 38-MDa plasmid was present in cells grown continuously for 10 days in steady state and in overnight batch cultures at $\mathrm{pH}$ 7.1. However, this plasmid was not detected in cultures grown continuously at $\mathrm{pH} 4.35$ or at $\mathrm{pH} 9.45$ (Fig. 3).

\section{Discussion}

A clinical isolate of Enteritidis PT4 was able to sustain growth over the $\mathrm{pH}$ range $4.35-9.45$, a range of relevance since it corresponds with the extremes of $\mathrm{pH}$ believed to be encountered in its environment in food products and during infection. For example, the $\mathrm{pH}$ of ovalbumin reaches $\mathrm{pH} 9.5$ during egg storage [6] whilst mayonnaise, which has repeatedly acted as the vehicle of Enteritidis outbreaks, may have a $\mathrm{pH}$ of $c .4$ $[18,19]$.

Generally, most bacteria of importance in foodborne diseases are unable to grow below $\mathrm{pH} 4.5$, which means that acidic foods do not normally present major health risks as far as the common bacterial agents causing food-transmitted disease are concerned [20]. The minimum $\mathrm{pH}$ for growth of $E$. coli and Salmonella serotype Paratyphi was estimated to be 4.4 and 4.5 , respectively, similar to those determined in this study. However, the maximum $\mathrm{pH}$ allowing growth of these two species was 9.0 and 7.8 , respectively; the $\mathrm{pH}$ range allowing growth of these two species is narrower than those determined for Enteritidis in this study. Comparable data on the $\mathrm{pH}$ range for the growth of other foodborne pathogens showed Bacillus cereus and Staphylococcus aureus to

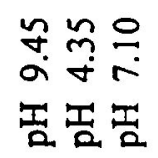

1234567891011121314

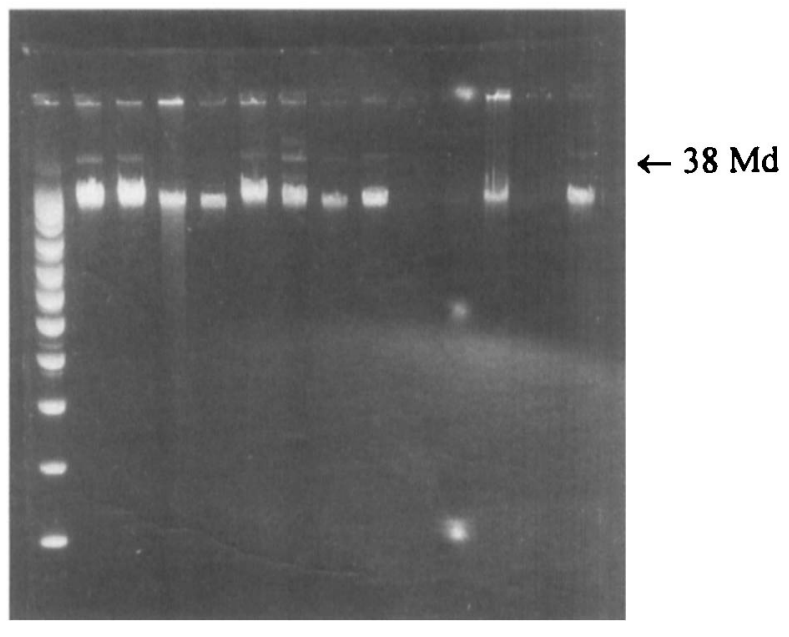

Fig. 3. Detection of plasmid DNA by agarose electrophoresis. Lanes: 1, mol.-wt ladder; 2, Pseudomonas aeruginosa strain RP4 containing a 36-MDa plasmid; 3, Enteritidis strain p132344; 4, Enteritidis strain 226405, sample stored at $-20^{\circ} \mathrm{C}$, from chemostat run at $\mathrm{pH} 9.45$; 5, Enteritidis strain $\mathrm{p} 132344 / 1 ; 6$, Enteritidis strain 226405 from L broth batch culture; 7, E. coli strain $39 \mathrm{R} 861 ; 8,9$, Enteritidis strain 226405, sample stored at $-20^{\circ} \mathrm{C}$, from chemostat run at $\mathrm{pH} 7.10 ; 10$, Enteritidis strain 226405 , sample direct from chemostat run at $\mathrm{pH}$ $9.45 ; 11$, as lane 10 but run at $\mathrm{pH} 4.35 ; 12$, as lane 10 ; 13 , as lane $11 ; 14$, as lane 10 but run at $\mathrm{pH} 7.10$.

have ranges similar to those detected in this study, i.e., 4.9-9.3, and 4.0-9.8, respectively. Wider ranges of $\mathrm{pH}$ tolerance were observed for alkali-tolerant bacteria such as Vibrio parahaemolyticus for which the limiting $\mathrm{pH}$ values for growth were between 4.8 and 11.0 [21].

The strain used in the present study was isolated from the faeces of an infected patient. The ability of Enteritidis strains to grow over such a wide $\mathrm{pH}$ range may not be a universal property as cultures of other strains became non-viable at $\mathrm{pH}$ values $<5.0$ [22]. Previous exposure to environmental stress may markedly influence the subsequent ability of bacteria to grow and survive. For example, brief incubation of Enteritidis in media at $\mathrm{pH}$ values between 3 and 6 resulted in a marked and rapid increase in the acid resistance of some cells [23]. The variation in the reported tolerance of different strains of Enteritidis PT4 to $\mathrm{pH}$ challenge may indicate either a variation within the phage type itself or may be a reflection of the different techniques $[24,25]$.

Growth at extremes of $\mathrm{pH}$ had significant effects on surface structures and plasmid carriage of cells. A reduction in the proportion of motile cells during continuous culture in comparison to those from batch 
cultures was observed, due perhaps to shearing forces, to the absence of nutrient gradients with continuous mixing or to the bacterial energetics, as organisms with the lowest energy requirements are selected in continuous cultures [26]. Synthesis of bacterial flagella and the accompanying array of chemotaxis receptors represents a major commitment of energy and resources for growing cells. The proportion of motile cells in cultures at extremes of $\mathrm{pH}$ was very low $(\sim 1 \%)$, and this value closely correlated with the number of cells possessing flagella. This observation suggests that the loss of motility was due to a shut down in the production of flagella; similar findings have been made with Campylobacter jejuni, in which the expression of sigma $54 f a \mathrm{~B}$ flagellin promoter was subject to environmental regulation. FlaB filament-protein production was affected by growth $\mathrm{pH}$, the composition of the growth medium and the temperature of growth [27].

Environmental $\mathrm{pH}$ had significant effects on the distribution of fimbriae on cells in the present study. Only $3 \%$ of cells grown at $\mathrm{pH} 9.45$ were fimbriate compared with $20 \%$ of cells grown at $\mathrm{pH} 4.35$ and $52 \%$ at $\mathrm{pH} 7.10$; these findings are in agreement with observations made on the production of fimbrial adhesins by enterotoxigenic $E$. coli during growth at various specific growth rates and at different $\mathrm{pH}$ values [28]. The production of fimbriae decreased at $\mathrm{pH}$ values above and below $\mathrm{pH} 7$ [28] and was also dependent on the growth rate of cells, with a significant production of fimbriae detected only at specific growth rate values higher than $0.2 / \mathrm{h}$; no significant differences were observed, however, between aerobic and anaerobic growth.

Salmonellae express many different types of fimbriae and Enteritidis has been shown to produce fimbrial structures differentiated as SEF 14, SEF 17 and SEF 21 [29]. In the present study, the effect of $\mathrm{pH}$ on the production of individual fimbrial types, was not determined and it is possible that particular fimbriae respond differently to specific environmental stimuli. The expression of SEF 14 has been shown to be influenced by the type of growth medium and, for one test strain, SEF 14 fimbriae were produced in peptone water at $\mathrm{pH} 7.2$ but not at $\mathrm{pH} 6.0[30]$.

A 38-MDa plasmid of Enteritidis has been associated with virulence in mice [11]. Despite the data from mouse studies, the relevance of this virulence plasmid in human infection remains unclear. For the strain tested in this study, the plasmid was detected in cells grown continuously at $\mathrm{pH} 7.10$ but not at $\mathrm{pH} 4.35$ or $\mathrm{pH}$ 9.45. The use of plasmid profiling for epidemiological investigation necessitates stable plasmids. Most studies of plasmid stability have been concerned with in-vivo stability of plasmid profiles for the duration of outbreaks. This $38-\mathrm{MDa}$ plasmid is reported to be very stable [31], but it may be that extreme environmental conditions of $\mathrm{pH}$ and nutrient availability induce changes in plasmid content and expression [32] and reduce the level of plasmidcarrying cells in the population to below the detection level of the assay. Even without direct selection, plasmid-containing bacteria may survive as a small minority of the population.

In order to determine whether the absence of motility and flagella during growth at $\mathrm{pH} 9.45$ was a phenotypic rather than a genotypic response, the presence of flagella on cells and motility was monitored when the $\mathrm{pH}$ fell from 9.45 to 7.10 . Flagella reappeared on cells almost immediately, suggesting that the response was, indeed, phenotypic and that expression of the relevant genes may be rapidly switched on or off in response to environmental stimuli.

In conclusion, Enteritidis was able to grow over a wide range of $\mathrm{pH}$ values, including those found in foods associated with outbreaks of disease. However, $\mathrm{pH}$ was also found to regulate markedly the expression of surface structures and the carriage of a 38$\mathrm{MDa}$ plasmid implicated in cell virulence. Consequently, the pathogenic potential of cells grown at different $\mathrm{pH}$ values should now be compared in a mouse model. Such studies should allow further insights to be made into the factors contributing to the virulence of Enteritidis PT4.

We acknowledge financial support from the Department of Health and thank Dr D. Bradshaw for assistance with statistical analyses.

\section{References}

1. Baird-Parker AC. Foodborne illness. Foodborne salmonellosis. Lancet 1990; 336: $1231-1235$.

2. Rodrigue DC, Tauxe RV, Rowe B. International increase in Salmonella enteritidis: a new pandemic? Epidemiol Infect 1990; 105: 21-27.

3. Advisory Committee on the Microbiological Safety of Food. Report on Salmonella in Eggs. London, HMSO. 1993.

4. Keller LH, Benson CE, Krotec K, Eckroade RJ. Salmonella enteritidis colonization of the reproductive tract and forming and freshly laid eggs of chickens. Infect Immun 1995; 63: 2443-2449

5. Humphrey TJ. Contamination of egg shell and contents with Salmonella enteritidis: a review. Int $J$ Food Microbiol 1994; 21: $31-40$.

6. Board RG, Clay C, Lock J, Dolman J. The egg: a compartmentalized, aseptically packaged food. In: Board RG, Fuller R (eds) Microbiology of the avian egg. London, Chapman and Hall. 1994: 43-61.

7. Smittle RB. Microbiology of mayonnaise and salad dressing: a review. J Food Protect 1977; 40: 415-422.

8. Vogel HJ, Bonner DM. Acetylornithinase of Escherichia coli: partial purification and some properties. J Biol Chem 1956; 218: $97-106$

9. Carlsson J. Chemically defined medium for growth of Streptococcus sanguis. Caries Res 1970; 4: 297-304.

10. Tempest DW. The place of continuous culture in microbiological research. In: Rose $\mathrm{AH}$, Wilkinson JF (eds) Advances in microbial physiology. 4. London, Academic Press. 1970: 223-250.

11. Chart H, Threlfall EJ, Rowe B. Virulence of Salmonella enteritidis phage type 4 is related to the possession of a 
38 MDa plasmid. FEMS Microbiol Lett 1989; 58: 299-304.

12. Portnoy DA, Moseley SL, Falkow S. Characterization of plasmids and plasmid-associated determinants of Yersinia enterocolitica pathogenesis. Infect Immun 1981; 31: 775-782.

13. Casse $F$, Boucher $C$, Julliot JS, Michel $M$, Dénarié J. Identification and characterization of large plasmids in Rhizobium meliloti using agarose gel electrophoresis. $J$ Gen Microbiol 1979; 113: 229-242.

14. Humphreys GO, Willshaw GA, Anderson ES. A simple method for the preparation of large quantities of pure plasmid DNA Biochim Biophys Acta 1975; 383: 457-463.

15. Tully M. A plasmid from a virulent strain of Legionella pneumophila is conjugative and confers resistance to ultraviolet light. FEMS Microbiol Lett 1991; 90: 43-48.

16. Threlfall EJ, Rowe B, Ferguson JL, Ward LR. Characterization of plasmids conferring resistance to gentamicin and apramycin in strains of Salmonella typhimurium phage type 204c isolated in Britain. J Hyg 1986; 97: 419-426.

17. Fisher LD, Van Belle G. Biostatistics: a methodology for the health sciences. New York, John Wiley and Sons. 1993: 187.

18. Perales I, García MI. The influence of $\mathrm{pH}$ and temperature on the behaviour of Salmonella enteritidis phage type 4 in homemade mayonnaise. Lett Appl Microbiol 1990; 10: 19-22.

19. Lock JL, Board RG. The fate of Salmonella enteritidis PT4 in home-made mayonnaise prepared from artificially inoculated eggs. Food Microbiol 1995; 12: 181-186.

20. Mossel DAA, Cory JEL, Struijk CB, Baird RM (eds) Essentials of the microbiology of foods: a textbook for advanced studies. Chichester, John Wiley and Sons. 1995.

21. International Commission on Microbiological Specifications for Foods. Microorganisms in foods. 3. Microbial ecology of foods. Vol 1, Factors affecting life and death of microorganisms. New York, Academic Press. 1980.

22. Chart H, Frost JA, Rowe B. Expression of outer membrane proteins by Salmonella enteritidis relating to $\mathrm{pH}$. FEMS Microbiol Lett 1994; 123: 311-314.
23. Humphrey TJ, Richardson NP, Statton KM, Rowbury RJ. Acid habituation in Salmonella enteritidis PT4: impact of inhibition of protein synthesis. Lett Appl Microbiol 1993; 16: 228-230.

24. Radford SA, Board RG. The influence of sodium chloride and $\mathrm{pH}$ on the growth of Salmonella enteritidis PT4. Lett Appl Microbiol 1995; 20: 11-13.

25. Rowbury RJ. An assessment of environmental factors influencing acid tolerance and sensitivity in Escherichia coli, Salmonella spp. and other enterobacteria. Lett Appl Microbiol 1995; 20: 333-337.

26. Pirt SJ. Energy and carbon source requirements. In: Pirt SJ (ed) Principles of microbe and cell cultivation. Oxford, Blackwell Scientific Publications. 1975: 63-80.

27. Alm RA, Guerry P, Trust TJ. The Campylobacter sigma 54 flaB flagellin promoter is subject to environmental regulation. $J$ Bacteriol 1993; 175: 4448-4455.

28. van Verseveld HW, Bakker $P$, van der Woude $T$, Terleth $C$, de Graaf FK. Production of fimbrial adhesins K99 and F41 by enterotoxigenic Escherichia coli as a function of growth-rate domain. Infect Immun 1985; 49: 159-163.

29. Collinson SK, Doig PC, Doran JL, Clouthier S, Trust TJ, Kay WW. Thin, aggregative fimbriae mediate binding of Salmonella enteritidis to fibronectin. J Bacteriol 1993; 175: 12-18.

30. Woodward MJ, Thorns CJ, Turcotte C. Fimbriae of Salmonella enteritidis: Molecular analysis of SEF14 and vaccine development potential. In: Cabello $\mathrm{F}$, Hormaeche $\mathrm{C}$, Mastroeni $\mathrm{P}$, Bonina L (eds) Biology of Salmonella. New York, Plenum Press. 1993: 79-82.

31. Olsen JE, Brown DJ, Baggensen DL, Bisgaard M. Stability of plasmids in five strains of Salmonella maintained in stab culture at different temperatures. J Appl Bacteriol 1994; 77: 155-159.

32. Caulcott CA, Dunn A, Robertson HA, Cooper NS, Brown ME, Rhodes PM. Investigation of the effect of growth environment on the stability of low-copy-number plasmids in Escherichia coli. J Gen Microbiol 1987; 133: 1881-1889. 